\title{
Em nome dos filhos ou "o retorno da lei do pai":' entrevista com Martin Dufresne
}

\author{
Carmen Susana Tornquist \\ Universidade do Estado de Santa Catarina
}

Publicar a entrevista de um homem numa revista feminista não é tarefa isenta de tensões e de desafios. Não que os homens estejam banidos do campo feminista, ao contrário: os estudos de gênero, particularmente no Brasil, desde há muito têm chamado atenção para o caráter sempre relacional da categoria, tema que envolve as pesquisas sobre masculinidade, e têm revelado suas complexidades, uma vez que o conceito também abarca hierarquias, poderes, hegemonias. ${ }^{2}$

Mas a tensão resiste na medida em que, ao adentrar no campo de estudos de gênero e dos movimentos feministas, muitos homens carregam junto com suas boas intenções os seus habitus de dominantes, contando, muitas vezes, com o beneplácito das mulheres, desejosas de acabar de uma vez por todas com as desigualdades e buscando a parceria dos homens na laboriosa e contraditória tarefa de transformar as relações entre os gêneros. Advertida desses riscos, ainda mais em se tratando de dar voz a um homem branco, intelectual e primeiro-mundista, gostaria de sublinhar que enfrentar essa discussão, justamente por toda a complexidade que comporta, e por acreditar que a temática da guarda compartilhada (ou conjunta), também abordada, é de grande importância para manter sob suspeita medidas institucionais e 'novos' comportamentos fartamente divulgados pela mídia, repleta de matérias

Copyright $\odot 2008$ by Revista Estudos Feministas

1 Referência ao artigo escrito pelo entrevistado juntamente com Hélène Palma (DUFRESNE e PALMA, 2002).

${ }^{2}$ Agradeço a Rosa Maria Rodrigues de Oliveira pelos comentários, bem como à equipe de editoras de Entrevistas da REF. 
entusiastas sobre a entrada em cena dos homens ditos cuidadores e/ou sensíveis. Isso conta com grande simpatia de setores influenciados pelo ethos contracultural, pelo feminismo difuso e pelo discurso da importância das relações sócioafetivas no âmbito da família, o que é compartilhado sobretudo pelas camadas médias urbanas, já que aponta para uma maior eqüidade entre homens e mulheres e o desejo de igualdade entre os sexos. Foi, sobretudo, nesse meio social que se fizeram os primeiros experimentos da guarda compartilhada, a partir de decisões judiciais nas varas de família e tribunais, que parecem, cada vez mais, estar aderindo, no caso do Brasil, a essas demandas, não sem articular tais propostas com a noção de medição e/ou de negociação, bastante apreciadas por operadores do direito e seus assessores/as, que tratam de assuntos relacionados a família. Esse sistema de guarda, que muitas vezes carrega consigo o fim do sistema clássico de pagamento de alimentos (pensão), tem sido apoiado por muitos juízes e desembargadores como Maria Berenice Dias, ${ }^{3}$ do Tribunal de Justiça do Rio Grande do Sul, que recomenda a guarda compartilhada, mas não sem trazer algumas advertências: a importância de analisar cada caso, de não haver rancores entre os ex-cônjuges para que a guarda seja, de fato, benéfica aos filhos, advertência que também aparece em outros estudos e/ou decisões judiciais. Maria Berenice Dias traz, ainda, recomendações acerca de possíveis problemas decorrentes de uma alternância (quando a guarda é, além de conjunta, alternada) entre modelos familiares e de educação diferenciados, um dos aspectos que muitas vezes provoca o divórcio ou se consolida após as reorganizações familiares de cada progenitor. Isso tem chamado atenção de estudiosos e profissionais que acompanham casos concretos que vêm ocorrendo nos países onde esse arranjo familiar é mais antigo, particularmente, na França e no Canadá.

A entrevista que segue, com o jornalista e ativista do movimento de homens pró-feminista no Canadá Martin Dufresne, foi feita durante $\circ 4^{\circ}$ Congresso de Pesquisadoras Feministas Francófonas, que aconteceu em Ottawa, em julho de 2005, após a apresentação do documentário In Nomine Patris - Ce que veulent les mouvements de pères. ${ }^{4}$ Dufresne também faz parte desse filme, como um dos profissionais entrevistados e como um dos divulgadores do trabalho no Canadá.

No Brasil, são recentes as mudanças no Código Civil no sentido de uma maior eqüidade entre direitos das mulheres e dos homens no que tange ao Direito de Família. O novo código foi promulgado em $2002^{5}$ e legitimou um conjunto importante de mudanças que já vinham ocorrendo há décadas na sociedade, particularmente no que se refere à moral e à organização familiar, na qual se inserem o divórcio e a situação dele

\footnotetext{
${ }^{3}$ DIAS, 2007.

${ }^{4}$ IN NOMINE PATRIS, 2005. Em nome do pai: o que querem os movimentos de pais. Tradução minha.

${ }^{5}$ BRASIL, 2002.
} 
decorrente, a definição da guarda dos filhos. ${ }^{6}$ Já a recente sanção da Lei 9.099/20087 faz eco a algumas das reivindicações históricas do feminismo, a saber, a des-naturalização da equação mãe-nutriz, pai-provedor, e a busca por uma divisão eqüitativa do trabalho doméstico e familiar, decorrente dessa desconstrução. Porém, cabe destacar que essa lei permite ao juiz definir, quando não há acordo dos pais e em nome do suposto bem-estar dos filhos, a guarda compartilhada.

O argumento dos direitos da criança, cada vez mais naturalizado em nossa sociedade, é central, por exemplo, nos discursos da humanização do parto e da amamentação natural, e é muito similar ao que é utilizado pelos discursos dos movimentos de pais, como podemos acompanhar nas várias matérias da mídia e nos sites da Internet que divulgam a temática. Ao que tudo indica, essa é a base de argumentação da lei recentemente promulgada no Brasil.

No caso do Québec, a institucionalização de uma série de demandas feministas, entre elas o direito ao divórcio, esteve no centro da chamada "Revolução Tranqüila", ocorrida nos anos 1960 e que influenciou sobremaneira o modo de vida e as relações entre os gêneros naquele país. No entanto, a reação a essas conquistas não tardou por se manifestar e teria, segundo Dufresne, no ramo do masculinismo (os simpáticos grupos de pais) uma das expressões mais fortes.

A visão de Dufresne, que aparece claramente aqui nesta entrevista, é representativa de um grupo de feministas, entre as quais Denyse Côté ${ }^{8}$ que desenvolveu uma pesquisa pioneira sobre o assunto mostrando a complexidade envolvida na questão da guarda compartilhada: de um lado, representa a consolidação de um novo modelo de família, mais favorável ao desenvolvimento pessoal das mulheres; de outro, apesar desse igualitarismo ideológico, pode, muitas vezes, significar uma reestruturação patriarcal, ${ }^{9}$ sobretudo quando não foi feita em comum e livre acordo entre os ex-cônjuges, mas sim com a imposição da Justiça ou do juiz, em nome do bem-estar das crianças. Essa advertência parece ser fundamental no Brasil, já que a Lei 9.099/2008 justamente outorga esse direito ao juiz.

A propósito, os estudos críticos que têm florescido no Brasil em decorrência dessa nova forma de gerir as famílias dialogam com essa tradição de pensamento, na qual estão presentes antropólogos/as, psicólogos/as, psicanalistas, assistentes sociais e advogados/as. ${ }^{10} \mathrm{O}$ que muitos dos autores e das autoras problematizam é que, em muitos casos, essa igualdade formal, mais facilmente incorporada, não corresponde a mudanças concretas no cotidiano e nas subjetividades: não raro, é ressignificada a partir de velhas estruturas patriarcais e

\footnotetext{
${ }^{6}$ Silvia AREND, 2006.

${ }^{7}$ BRASIL, 2008.

${ }^{8}$ CÔTÉ, 2000.

${ }^{9}$ CÔTÉ, 2004.

${ }^{10}$ Como, por exemplo, Eduardo de Oliveira LEITE, 2003; Françoise DOLTO, 1989; e Gerard POUSSIN e Elisabeth MARTIN-LEBRUN, 1999.
} 
acaba por legitimar o poder masculino sobre a sua ex-mulher, através do chamado direito de paternidade. Em nome dos filhos, muitos desses simpáticos movimentos de pais ${ }^{11}$ representariam, antes, uma reação conservadora ao avanço dos diretos destes 'novos' sujeitos contemporâneos: mulheres e crianças.

Martin Dufresne não hesita em referir-se a esse braço paternal do masculinismo como um movimento de direita, chamando atenção para as correlações diretas entre a nãoaceitação do direito de escolha da mulher quanto à manutenção do casamento (já que a guarda conjunta não pode ser analisada sem considerar direito ao divórcio) e as violências que, enquanto fenômeno social, seguem produzindo maridos agressores e mulheres agredidas. Essas violências, muitas vezes, se aprofundam após a separação e por ocasião das 'visitas' e 'vistorias' feitas pelo pai ao domicílio da mãe, como mostra o estudo de Denyse Côté, ${ }^{12}$ e se dão num plano não necessariamente físico, mas naquele nível mais sutil pelo qual o poder se exerce, o da violência simbólica, para o qual conta, infelizmente, com a cumplicidade de muitos mediadores, psicólogos e operadores do direito, imbuídos da defesa incondicional dos direitos das crianças, direitos esses, ao que me parece em países como o Brasil, mais palatáveis do que os direitos das mulheres.

Espero que a entrevista possa contribuir com a necessária reflexão, crítica e cautelosa, sobre a temática dos movimentos de homens (do masculinismo ao Laço Branco), bem como sobre a guarda conjunta, que enfatizamos nesta apresentação. Esta última requer bem mais do que notícias jornalísticas e análises superficiais que apenas celebram as virtudes dos pais cuidadores, e que não dão voz às análises a partir de um ponto de vista feminista, ainda que incipientes em nosso país, de como as decisões e acordos judiciais são vivenciados no cotidiano das famílias recompostas, sobretudo num momento em que, na América Latina em particular, a reação conservadora atinente ao corpo das mulheres e aos seus direitos humanos está mais uma vez, e violentamente, colocada no centro da cena política.

\footnotetext{
"SOS Papa (França), Fathers for Justice (Londres), Condition Parentale et Familiale (Grenoble), Mouvemente Égalité Parentelle (Bélgica), Vaterauchbruch für Kinder (Alemanha).

${ }^{12}$ CÔTÉ, 2004.
} 
Carmen Susana Tornquist: Você é conhecido por suas atividades como pesquisador e militante. Poderia falar sobre elas?

Martin Dufresne: Na verdade, sou mais um militante que um pesquisador universitário. Minha formação acadêmica é em ciências puras, mas, no fundo, foi em meu trabalho como cenarista de televisão que comecei a pesquisar sobre as mulheres e relações de sexo, o que me levou à pesquisa participante, a participar mais que simplesmente escrever ficção - porque uma verdadeira revolução estava então em curso no Québec. O movimento feminista já tinha mais de 30 anos quando comecei a me envolver; eu simplesmente me juntei às lutas. E logo a palavra de ordem que as mulheres nos davam, aos poucos homens que participavam do movimento, era esta: "falem aos homens, façam um trabalho de educação mas também de análise do que representa a condição masculina dos dominantes para desconstruí-la". Isso quer dizer que nós executávamos um trabalho tático, logístico, de modo voluntário para alguns homens pró-feministas, aceitando prestar contas ao movimento das mulheres sobre a questão da dominação masculina, o modo de fazê-la recuar e a análise das novas formas de controle, de apropriação e de violência simbólicas e físicas impostas às mulheres individual e coletivamente.

CST: No Brasil, nos últimos anos, temos tido contato com o Movimento Laço Branco (White Ribbon Campaign), que teve origem aqui no Canadá. Poderia nos falar sobre esse movimento?

MD: É necessário lembrar que em 1989, no Canadá, um homem de 25 anos, que teve sua inscrição para a Escola Politécnica de Montreal rejeitada por causa de insuficiência de notas, decidiu fazer do movimento feminista o bode expiatório. Alimentado pela propaganda masculinista cheia de rancor, no dia 6 de dezembro de 1989 investiu com uma metralhadora contra a Universidade de Montreal e matou o maior número possível de estudantes e uma funcionária do serviço de admissões, acusando-as de serem feministas. Para ele, o fato de mulheres terem podido ingressar numa faculdade de gênios, e ele ter sido rejeitado, era o símbolo do fato de os homens terem perdido muitas prerrogativas, de que as mulheres haviam adquirido demasiadas, e que era hora de efetivar um gesto clamoroso para intimidar as mulheres, para fazê-las se retirarem, enfim, de lugares como essa faculdade e também do exército, dos serviços policiais e dos bombeiros, que eram, em sua opinião, fundamentalmente masculinos. Ele deixou um manifesto muito claro a esse respeito, um texto que, durante muito tempo, esteve afixado com comentários favoráveis na Web em sites masculinistas internacionais e quebequenses. Embora fosse proclamado que o gesto tinha sido deplorável, no fundo, as pessoas mostravam sua concordância com a motivação de um crime no qual 14 mulheres haviam sido assassinadas e 29 mulheres e homens feridos por esse militante 
anti-feminista, Marc Lépine. Esse acontecimento chocante foi como que o ponto de partida para uma guerra aberta contra o feminismo no Canadá por pessoas que ainda lá, sem acatar abertamente o gesto de Lépine, têm assim mesmo encarado seu crime sob o pretexto de que "é verdadeiro em todo o caso, foi-se longe demais, os homens sofrem, os homens têm depressão". Há nisso todo um discurso psicologizante de queixa dos homens, que ainda cerca não só as feministas, como também qualquer mulher de hoje, para intimidá-las e incitálas a serem mais sensíveis e respeitosas diante da raiva crescente que o masculinismo insufla entre os homens.

A Campanha do Laço Branco, criada no dia seguinte ao massacre da Escola Politécnica - recuperando um símbolo da paz escolhido por mulheres durante uma cerimônia -, representa, desse ponto de vista, uma reação bem minoritária de homens que, paradoxalmente, se dizem pró-feministas e usam 06 de Dezembro de cada ano para apresentar os homens como não-violentos e bem intencionados: eles não têm mais que usar um laço azul nesse dia para comprová-lo. Eu sou muito cético: os líderes desse movimento manifestam igualmente uma ideologia paternalista, com uma homenagem anual aos pais. Uma pesquisa aprofundada de Roberta Spark demonstrou que os criadores dessa campanha esbanjaram muito dinheiro - que eles tinham recolhido para o movimento das mulheres, em seu início, mas do qual elas não viram um vintém, infelizmente.

CST: Em sua opinião, haveria uma especificidade do Canadá ou do quebequense na questão do feminismo? Se a gente considerar a chamada "Revolução Tranqüila", à qual você se referiu antes...

MD: No Québec - porque houve ali uma assim chamada "Revolução Tranqüila", certamente uma reforma muito rápida das instituições - vivenciou-se uma aceleração, ao longo dos anos 60, que instigou o feminismo quebequense. Vários feminismos se desenvolveram no final dos anos 60 em diferentes países ao mesmo tempo, mas o feminismo do Québec beneficiou-se do impulso desse movimento de reforma das instituições, do sistema de ensino, do casamento, da justiça, da sociedade em geral. Por exemplo, as mulheres não tinham direito de assentar-se em um júri até 1973 no Québec. Assim, o feminismo quebequense nutriu-se, em parte, da Revolução Tranqüila; de outra, do fato de muitas reformas sociais terem sido conduzidas pelo aparelho de Estado, porque esse aparelho foi de repente constituído por pessoas egressas de universidades no fim dos anos 60. Dessa forma, muitas reformas que, em muitos outros países, foram realizadas bem ou mal contra o Estado aqui foram feitas com e pelo Estado, embora nem sempre de modo harmonioso; ainda assim, o Estado financiou, autorizou e permitiu aos pesquisadores e militantes a instauração de uma rede de serviços e uma rede de grupos comunitários que, do ponto de vista prático, deram ao feminismo quebequense um dinamismo incomum em todo nosso planeta. 
Nesse sentido, pode-se dizer que o feminismo no Québec estava suficientemente afastado, não muito distante, penso eu, para constituir uma espécie de farol, de prova do que era verdadeiro e possível para muitos pesquisadores e para o movimento das mulheres. Por outro lado, o Canadá e o Québec são sociedades menos politizadas que muitos outros países, os quais, desde muito tempo, fizeram justamente e com mais facilidade a distinção entre os interesses das classes populares, os interesses das classes dominantes e o jogo do Estado, fato que se reflete em partidos políticos de tendências várias. No Québec, onde vivo, nenhum partido de centro-esquerda ou de esquerda tem o poder atualmente, o que significa dizer que se trata de uma sociedade praticamente familiar fundada sobre valores tomados como coletivos. O feminismo, pois, impôs-se bem mais no nível dos valores e de um consenso buscado pela população do que a partir de um enfretamento explícito contra instâncias estabelecidas há tempo, ou forças políticas, como nos países europeus ou sul-americanos, onde se distinguem mais claramente as forças de esquerda e de direita.

No que diz respeito ao masculinismo, o quebequense, a meu ver, está menos desenvolvido que nos Estados Unidos ou no Reino Unido, mas o quebequense também desfruta de certas subvenções e apoios das mídias de direita para influenciar a coletividade em função de interesses de homens violentos ou corruptos. Então, existe de algum modo um impacto quanto ao masculinismo que não é negligenciável. Aliás, os masculinistas canadenses estão conectados com organizações equivalentes nos Estados Unidos, na Austrália, na Nova Zelândia e em alguns outros países que se organizam para impor atualmente seus objetivos à Europa. Na França, na Bélgica, na Suíça, na Alemanha e na Itália há grupos que envolvem os homens em torno de certas intolerâncias, as quais, infelizmente, com muita facilidade, são aceitas pelo Estado, tais como suprimir ou reduzir as obrigações dos homens que se casam novamente em relação aos filhos do primeiro casamento, instituir a guarda compartilhada estatutária e paralisar toda intervenção judicial contra os cônjuges agressores ou pais agressores em relação a seus filhos. Observa-se o desenvolvimento de um plano de ação masculinista, retomado de país em país, para fazer regredir, no fim das contas, o direito das mulheres e das crianças de se livrar da violência e do poder desses homens.

CST: Você não usa a expressão "homem feminista", mas "pró-feminista". Poderia explicar o sentido dessa categoria?

MD: Há alguns homens que se dizem "feministas" que utilizam a expressão "homem feminista" para manifestar o caráter integral dessa implicação, o que é louvável. É isso que faz, por exemplo, John Stoltenberg, que escreveu vários textos importantes do movimento (Refusing to Be a Man, The End of Manhood). Quanto a mim, julgo que "pró-feminista" é mais claro porque coloca, de modo bem explícito, nosso apoio a um movimento autônomo, inteiramente livre em suas escolhas. Há homens demais se dizendo feministas ditando ao movimento 
das mulheres aquilo que elas deveriam fazer - e isso eu mesmo fiz tempos atrás. E ainda hoje em alguns processos controvertidos, como a prostituição, por exemplo, é muito delicado não lançar mão da autoridade masculina, de um tom de voz bem masculino para tentar impor uma leitura - a qual, de tanto ouvir as mulheres, tornou-se para mim uma evidência, a saber, que a prostituição é uma violência masculina dirigida contra as mulheres, mas, ao mesmo tempo, respeitar o fato de que as mulheres buscam obter consenso entre elas mesmas para distinguir aquilo que é poder masculino e aquilo que é resistência das mulheres e estratégia das mulheres. Evitou-se, sobretudo, essas escolhas controversas para concentrar em todo o caso o que representava a função e os interesses masculinos nessas questões. De certo modo, nossa análise do movimento anti-feminista, o masculinismo, forneceu o terreno onde se podia analisar a organização do poder masculino e sua reprodução. Isso nos permite talvez mesmo resolver certas controvérsias ou contradições, mostrando que os homens agem conscientemente em seus componentes sexistas e deles tiram cotidianamente benefícios.

\section{CST: Há muitos homens nesse movimento?}

MD: Infelizmente há poucos; na verdade, é uma microrede. Fala-se em uma dezena de homens no Québec, mas é algo pontual, quando há uma causa que a mídia difunde, na qual está claro que o patriarcado procura endurecer uma de suas posições, e então nós vamos procurar ajuda de muitos outros homens. Por exemplo, o lobby masculinista tentou faz pouco derrubar o Conselho do Estatuto da Mulher, que, no Québec, é uma instância de promoção dos direitos das mulheres à igualdade. Nesses momentos, a gente dirige apelos a todos, nos meios comunitários, sindicatos, nos jornais, na Internet; coletam-se assinaturas de homens progressistas, solidários com as mulheres. A primeira vez que fizemos isso foi em 1989, quando um homem tentou impedir sua companheira de fazer um aborto, obtendo um mandado nas Cortes Superiores, a fim de impedi-la de abortar depois de tê-la forçado a abandonar os anti-concepcionais. Enquanto as mulheres se mobilizavam, nós fizemos um apelo aos homens, e várias centenas deles concordaram em subscrever uma carta de solidariedade à senhora Chantal Daigle, a mulher visada no processo, que era sustentado pelo lobby anti-aborto. Mais recentemente, contra a extinção do Conselho do Estatuto da Mulher, foram colhidas 750 assinaturas de homens, a maior parte deles sindicalizados ou participantes do movimento comunitário. Somos solidários com o trabalho de promoção da igualdade das mulheres que é desenvolvido pelo Conselho do Estatuto da Mulher e fazemos oposição ao movimento masculinista que pretende representar os homens.

Esse é também um dos aspectos simbólicos importantes de nossa função, quer dizer, impedir os homens de direita de pretenderem representar a coletividade masculina e insistir no fato de que os homens se afastem das fratrias patriarcais que 
têm as mulheres sob controle e combatem o movimento delas. Nossa presença não invalida uma análise feminista radical; nós participamos dela: nós pensamos que os homens operam, no fundo, como um grupo de dominantes solidários que se valem de diferentes estratégias para a manutenção de seus privilégios, mas nós insistimos, nós incitamos até, os homens a optar pela dissidência, por um apoio ativo às mulheres, evidentemente trabalhando para reduzir seu próprio sexismo.

CST: Como reagem as feministas à atuação do movimento dos homens pró-feministas do Canadá?

MD:O movimento dos homens pró-feministas está muito pouco desenvolvido, infelizmente. Buscam-se em ocasiões especiais alguns nomes importantes quando há um processo particularmente quente, uma causa célebre, mas se a gente fala sobre os homens que fazem no dia-a-dia esse trabalho de vigilância, de análise estratégica das agendas e de preparação de intervenções, então se fala de uma dezena de homens. Somos um grupo pouco numeroso. Por outro lado, nossos atos de solidariedade com as mulheres são muito positivos. Recebo um número incontável de manifestações de reconhecimento de mulheres, e de apreço que, aliás, vão bem além de meus méritos reais. Evidentemente, permanecem algumas controvérsias importantes. Por exemplo, as mulheres sofrem muita pressão para se afastarem do trabalho não misto. Muitos homens querem Ihes impor a própria presença, e algumas mulheres sustentam essa presença em nome do "humanismo". Ocorre que algumas pessoas tentam se valer de nosso movimento para forçar as mulheres a abrir seus espaços e suas instâncias aos homens. É-lhes dito: "Vejam bem! Já que existem homens pró-feministas, vocês estão erradas, vocês são sectárias quando exigem trabalhar entre mulheres". Essa, de maneira alguma, é minha posição. Nós observamos muito entrismo da parte dos homens anti-feministas: esses homens se inscrevem em movimentos mistos e tiram proveito da demanda de apoios vindos das mulheres para desviar as prioridades dessas organizações - organizações de progenitores (pais e/ ou mães) que vivem sós, por exemplo - em proveito das prioridades masculinas. Nesse sentido, nós temos sempre defendido o direito das mulheres de trabalharem em grupos não mistos, se for escolha delas. Em nossas interações com as mulheres, ficam evidentes essas tensões porque existem mulheres que preferem trabalhar em grupos não mistos, enquanto que nós não podemos trabalhar no cotidiano, a não ser com os outros. Haverá sempre tensões porque, entre outros motivos, mesmo os bem intencionados têm ainda hábitos masculinos de controle, de violência verbal, de desatenção, de falta de cumprimento a compromissos assumidos. Uma de nossas prioridades é de ser aqueles que resistem aos masculinistas, que impõem, às vezes, formas de enfrentamento grosseiramente violentas, provocativas sem motivo, uma tática de intimidação. Ao mesmo tempo, não é dito que as mulheres não possam também optar pela provocação. Então, é sempre 
para nós trabalhoso retomar o questionamento e distinguir se nós cometemos erros enquanto homens ou se nosso comportamento foi suficientemente responsável e levado em conta por nossas aliadas. A solução é aceitar sermos accountable, de sermos devedores, prestar contas às mulheres. Num encontro de homens organizado pela Universidade de Montreal por masculinistas europeus e quebequenses, trabalhou-se aproximadamente 30 dias em coalizão mista e ainda hoje estamos tentando analisar os momentos mais difíceis nos quais alguém, como eu, que sou mais velho e tenho a experiência com a palavra, pode desviar a fala das mulheres presentes, respondendo rapidamente a oponentes quando eu teria por obrigação dar prioridade da palavra às feministas presentes. A gente não se falou suficientemente, o que criou um mal-estar. É, pois, um exemplo do fato de que um homem feminista continua sendo considerado portador de um poder masculino tradicional. Ele tem ainda mais poder, uma vez que se mostra mais progressista que os outros homens, e é uma questão muito delicada chegar a tentar encontrar coletivamente modos de agir para que a força da análise, 0 agenciamento político das mulheres permaneça no primeiro plano, mais que simplesmente restabelecer os hábitos tradicionais de controle masculino do discurso público. As interações entre mulheres e homens nesses processos são verdadeiramente portadoras de progresso. Para mim, é onde aprendo a maior parte das coisas. Se houvesse mais homens pró-feministas, nós teríamos desenvolvido uma análise mais avançada... Mas não se deve também atribuir ao fato de sermos poucos homens não haver um expressivo desenvolvimento teórico, porque a realidade é muito simplesmente esta: a maioria dos homens permanece solitária, silenciosa, senão cúmplice ante o sexismo e, em todo caso, eles continuam a eleger governos majoritariamente masculinos que tomam decisões que continuam a proteger os privilégios masculinos. Nesse sentido, para mim nossa experiência - já faz ao menos 30 anos que eu trabalho nessa área, e 25 dentro de um grupo organizado valida plenamente a análise feminista radical de uma solidariedade da fratria masculina como composta de dominantes que protegem benefícios por razões interesseiras. Minha experiência contradiz a análise liberal que sugere que os homens seriam, sobretudo, vítimas inconscientes do sexismo, e que é necessário nos congratularmos por eles se organizarem para promover seus interesses.

CST: No filme In Nomine Patris: o que querem os movimentos de pais, há testemunhos de homens que participam do movimento masculinista em diferentes países. Poderia nos dizer alguma coisa sobre esse movimento na América do Norte e em países europeus?

MD: Seria muito ampla a resposta a essa questão, mas digamos que sempre existiu uma fratria masculina de solidariedade em torno de certos privilégios de apropriação das mulheres, de seu trabalho, de seus filhos, e esse movimento 
utilizou diferentes táticas, em diferentes momentos, sobretudo no momento em que o movimento das mulheres crescia ou tentava crescer. Então, havia da parte dos homens discursos naturalistas ou, pelo contrário, referências a uma pretensa discriminação sofrida pelos homens devido ao progresso das mulheres, para mobilizar os homens e intimidar o poder público para que não se dessem ouvidos à reivindicação de igualdade por parte das mulheres. Hoje esse movimento está particularmente ativo no campo do direito da família, porque obtém facilmente apoios entre os homens que tentam entravar uma iniciativa de sua cônjuge, recusam-se a pagar uma pensão alimentícia, tentam controlar a vida da família que continua, ou tentam escapar a toda e qualquer sanção à violência conjugal ou incestuosa que exerçam contra a família. Esse movimento encontra apoio também junto ao patronato, para lutar contra medidas de eqüidade salarial, e junto à lgreja Católica, para se contrapor à legalização do aborto.

No fim das contas, se examinarmos cada reivindicação das mulheres, cada um dos problemas de sexismo que elas levam à praça pública, podemos balizar uma oposição sistemática destes grupúsculos de homens. São anti-feministas e, apesar de sua violência e seus atos ilegais, eles encontram uma platéia naturalmente complacente junto a governantes e a mídias que resistem ao avanço das mulheres. Vê-se o poder utilizar esses homens de certa forma como símbolos, mercenários incumbidos de desacreditar, mais uma vez, as mulheres, seja o movimento das mulheres, sejam mulheres individualmente. Trata-se de restaurar formas bem tradicionais de poder masculino e de misoginia, mas o masculinismo quer também criar novas formas de poder masculino, novos privilégios masculinos, como, por exemplo, o de generalizar e liberalizar o acesso das mulheres ao mercado da prostituição e da pornografia, do mesmo modo que cessar os interditos sobre o incesto e outras formas de violência masculina que se agravam na atualidade.

CST: Você tem sido uma das muitas pessoas que analisam, de forma bastante crítica, a questão da guarda compartilhada ou da guarda conjunta de filhos/as, decorrente dos processos de recomposição familiar que se tornaram correntes com a formalização do divórcio. Poderia nos falar sobre esses processos, tendo por foco o contexto do Canadá?

MD: O divórcio não estava autorizado até 1968 no Canadá. Na verdade, as instituições religiosas controlavam muito estreitamente os direitos das mulheres e, apesar de os homens poderem abandonar suas mulheres, estas não tinham o direito de mandar anular seu casamento e de conseguir o sustento de seus filhos, o que criou situações sociais extremamente penosas. Com a chegada de um regime público de assistência social e com a relativa baixa da influência da religião cristã, o divórcio foi instituído em 1968 e permitiu, evidentemente, o reconhecimento da guarda dos filhos àquele ou àquela que a desejasse ou que fosse reconhecidamente 
capaz de exercê-la, mas às vezes sem a autoridade parental correspondente. A interação das competências provinciais e federais é bastante complexa no Québec; por exemplo, no caso de separação, a autoridade paterna permaneceu até 1982. Isso significa que, mesmo se uma quebequense tivesse a guarda exclusiva de seus filhos e lhes assegurasse a educação, ela deveria, mesmo assim, colher a assinatura do ex-cônjuge para toda decisão importante relativa às crianças, fato que criava situações intoleráveis. Em 1982, uma autoridade parental conjunta foi instituída oficialmente no Québec, deixando, mesmo assim, o problema da busca de um acordo com um parceiro intolerante, ou vingativo, autorizado a fazer obstruções. Quando as pessoas se divorciavam, o que decorre de lei federal, era mais simples porque nesse momento decidia-se quanto à guarda física da criança, à responsabilidade das principais decisões concernentes a ela. Mas isso está mudando. A reivindicação masculinista atual de uma guarda compartilhada estatutária, da supressão mesma de todo reconhecimento de guarda, isto é, a responsabilidade das principais decisões aí implicadas, isto é, o trabalho correspondente à guarda física da criança, marcaria um grave retrocesso. Recairíamos na situação tradicional em que o homem pode ser violento, ou completamente ineficiente e mesmo perigoso como pai, e conservar, se o desejar, para além de toda separação ou divórcio, a possibilidade de agir sobre qualquer decisão de sua ex-parceira, fato que dissuadiria muitas mulheres violentadas a se divorciar. Além disso, pode-se entender muito claramente no discurso masculinista sua oposição absoluta, visceral ao direito das mulheres ao divórcio. Evidentemente, os homens vão sempre poder conservar o direito de fugir ou de ignorar suas responsabilidades, mas as mulheres perderiam esse direito de fugir do par disfuncional se quiserem proteger seus filhos, porque os pais conservariam a mão pronta a agir em toda decisão de sua parte em relação às crianças. Sua questão, portanto, sobre o direito ao divórcio é muito apropriada, porque é isso que está hoje ameaçado pelo putsch masculinista que tenta instaurar, com bases naturalistas, o poder absoluto do pai sobre a mãe biológica de seus filhos, sem atentar para seus méritos ou defeitos.

CST: Nesse sentido, a guarda compartilhada de hoje poderia ser considerada uma nova estratégia masculinista?

MD: Ancorado nos supostos "direitos dos homens", o masculinismo investiu muito nas fórmulas da guarda das crianças e da autoridade parental conjunta. É importante estabelecer a diferença entre uma residência alternada e uma verdadeira parceria simétrica dos deveres parentais, o que é raro, e uma simples autoridade parental conjunta, o que, afinal, significa um direito de veto masculino, a manutenção da autoridade paterna sobre a família independentemente de quem assegura a maior parte ou a totalidade dos cuidados com as crianças. $O$ que os masculinistas tentam impor em todos os lugares é um regime estatutário de guarda conjunta. Para 
um bom número de mulheres, é preciso entender que isso equivale, na prática, a suprimir o direito ao divórcio, quer dizer, o direito de romper com um parceiro violento ou toxicômano ou completamente desinvestido de seu papel parental e que, por uma ou outra razão, não permite à família atingir e manter um nível mínimo de bem-estar. Parece-me muito importante assegurar o direito ao divórcio que as mulheres conquistaram após longas lutas contra as instituições religiosas. O movimento masculinista tenta, na verdade, colocar o poder dos homens a abrigo da separação ou do divórcio, porque o modelo de autoridade parental conjunta é de não exigir das duas partes uma participação igual nos cuidados das crianças e suas necessidades. Para a lei, trata-se simplesmente da autoridade do não-guardador. O que está em jogo é também a divisão ou não dos recursos financeiros materiais (bens domésticos e pensões alimentares para as crianças ou a ex-parceira). No plano da imagem, da ideologia, vêem-se esses homens apropriarem-se, com a cumplicidade das mídias liberais, daquilo que fora, de início, uma reivindicação das mulheres: a partilha igualitária da atenção às crianças para impor às mulheres, via Estado e tribunais, um retorno da autoridade masculina e, por vezes, uma abolição da partilha dos recursos financeiros dos homens, porque, justamente, a ideologia nos leva a acreditar que o homem, tendo a guarda conjunta, vai dividir os cuidados com as crianças. Assim, o mito da igualdade é usado para restaurar a iniqüidade tradicional segundo a qual o homem controla o dinheiro, controla os bens e tem igualmente acesso a certos níveis de vantagens atribuídas aos pais, e isso independentemente do trabalho que ele vai fazer ou não com as crianças. Penso, pois, que, quando se considera uma solicitação de guarda conjunta, antes de mais nada é necessário ter isto muito claro: será que cada um dos pais deseja mesmo essa fórmula? Porque, se um dos dois pais não a deseja realmente ou a deseja apenas para evitar o pagamento da pensão, é injusto para o guardador e isso não funcionará.

Veja-se, pois, que há duas excelentes razões para resistir à tentativa de fazer da guarda compartilhada uma norma a ser sistematicamente aplicada pelo Estado ou por tribunais ou por mediadores. Mas, infelizmente, é isso que está sendo produzido no Canadá e na Europa sob pressão do movimento masculinista, embora determinados estados americanos como a Califórnia e Nova lorque reconheçam hoje as imperfeições dessa tendência da qual foram os pioneiros.

$\mathrm{Na}$ verdade, há ainda outras questões importantes a levantar. Por exemplo: serão os dois ex-cônjuges igualmente capazes e respeitosos para com a criança para receberem a atribuição como pessoas que terão direitos sobre as decisões fundamentais de proteção dos interesses dessa criança? Se a gente acaba cometendo o erro, como acontece cada vez mais no Canadá, de confiar as crianças a homens violentos, toxicômanos, depressivos ou homens que não aceitam o divórcio e que se servem das crianças para se vingar da parceira, promete-se às crianças um futuro muito triste. A situação pode mesmo chegar ao assassinato, porque isto está acontecendo: 
homens incompetentes ou perigosos obtêm a guarda compartiIhada ou 'direitos' de visita e matam as crianças. Isso acontece no Québec duas a três vezes por ano, desde que esse tipo de fórmula começou a ser aplicada quase sistematicamente. Bem, homens matavam seus filhos antes, e não quero valer-me de um argumento muito pesado do que pode parecer relativamente episódico, mas o princípio de uma avaliação caso a caso, em vista do interesse da criança e da competência de cada um dos pais postulantes, é uma vitória da eqüidade. As mulheres conseguiram tirar o poder e a violência intra-familiar da esfera privada para levá-la à praça pública e impor à sociedade a responsabilidade de decidir coletivamente e de proteger as pessoas vulneráveis dessas pressões. É uma regressão muito rápida desse princípio o que se vê atualmente porque, ao se instaurar a guarda partilhada sistemática, no fundo, reenviam-se ao privado e remetem-se a negociações que, em geral, têm lugar entre dominante e dominado, sem intervenção de uma instância objetiva, decisões que podem ter conseqüências pesadas em termos de segurança das pessoas e de eqüidade.

CST: Desde quando a guarda compartilhada é aceita pela justiça do Canadá?

MD: Ao contrário da França, onde a residência alternada era interditada e vista como nociva para a criança até 15 anos atrás, observou-se sempre no Canadá a aceitação pelos tribunais das distribuições de guarda que representassem um consenso entre os pais. Temos mesmo no Canadá um sistema no qual as pessoas podem acordar divórcio ou separação sem necessidade de recorrer ao tribunal, se não estiverem em litígio. Quanto aos julgamentos de atribuição da guarda compartilhada, estes datam do começo da legislação sobre o divórcio de 1968. Mas tratava-se mais freqüentemente de uma guarda exclusiva, resultado de um acordo, porque quando os pais recorrem ao tribunal é comum estarem em litígio, e os tribunais reconheciam, até duas décadas atrás, que, havendo grande animosidade entre os pais, eles raramente poderiam dividir harmoniosamente a guarda das crianças. Quando a guarda compartilhada começou a ser objeto de promoção muito ativa, por diferentes razões, em geral financeira para o homem, mas também porque o poder paternal tornava-se uma estratégia política para ambos, alguns quiseram manter 0 controle sobre a ex-parceira; é, pois, a partir dos anos 80 , penso eu, que tais acertos começaram a ocorrer. Mas foi então que os masculinistas - primeiro nos Estados Unidos, depois em vários outros países - investiram na estratégia de fazer valer, em nome da humanização do processo, uma manobra diversionista aos precedentes e às garantias do direito da família, a conciliação ou a mediação. Trata-se de um projeto de privatizar o direito de família, desejado pelos homens que têm muito a perder em julgamentos apoiados na eqüidade e no interesse da criança, decisões que os obrigam ao pagamento da pensão alimentar e à divisão dos bens. 
Eles visam a uma 'desjudiciarização' para poupar gastos com advogados, para ter o Estado a seu lado e para forçar as mulheres a entendimentos consensuais, nos quais evidentemente o devedor tem todo o interesse de se mostrar inflexível. Isso é o mesmo que dar a ele uma faca afiada. Quando a mediação começou a ser instituída e cada vez mais regulada pelo Estado em relação aos pais em instância de separação, surgiram mediadores a recomendar sistematicamente a guarda compartilhada aos casais que vinham se aconselhar com eles - mesmo casais em conflito aberto -, e em certos casos, quando autorizada, era recomendada ao tribunal. E chegou-se mesmo a ver tribunais impondo a guarda compartilhada a pais que não a queriam, habitualmente à mãe que não a queria contra o pai que a queria. Era o que se configurava mais freqüentemente, mas foram até o ponto de impô-la quando não a queria nem um nem outro. Cada um dos ex-cônjuges postulava uma guarda exclusiva e o magistrado se permitia despachá-los sem decidir, dizendo: "Procurem entendimento; cada um de vocês tem o direito de impedir o outro de ser pai". E isto se transformou no discurso dominante: a noção de que um pai, tendo uma guarda compartilhada, tinha o privilégio incluído, mesmo se a iniciativa fosse de um parceiro que o abandonava! Era apesar disso uma inversão da realidade quando se conhece a dimensão de trabalho que envolve a educação das crianças. Poder-seia mesmo analisar por que essa inversão de costumes é tão sedutora e convincente. Penso que existe aí implicado um fantasma do pai que nos impede de ter a honestidade de ver a pessoa não implicada e sua estratégia como um elemento de peso nessas situações. Em suma, tem-se começado a impor guardas compartilhadas sem o acordo dos dois genitores, 0 que tem permitido ao movimento masculinista ir mais longe e postular que a guarda compartilhada se torne o modo estatutário, salvo em casos de verdadeira força maior em que é evidente que um dos progenitores está ausente, ou é de tal modo violento que não se possa esperar que queira mudar. Mas, mesmo em situações de violência familiar, sobraria o encargo, àquele que já exerceu a guarda e que vai continuar a exercê-la, de provar que o outro não merece ser considerado como um co-parent e de controlar todas as decisões do genitor que realmente exerça a guarda. É infelizmente o sistema que se corre o risco de ver imposto em definitivo no Canadá. Vai ser muito difícil resistir a essa fórmula, porque ela já foi instaurada na França, na Bélgica, na Nova Zelândia, e em certos estados dos Estados Unidos da América, e isso apesar das pesquisas que têm demonstrado o caráter disfuncional dessas soluções impostas contra o desejo dos pais. Infelizmente, é muito cômodo para o Estado e para os tribunais lavar as mãos sobre decisões que eles devem enfrentar; são pais orgulhosos de sua indignação masculina. É um modo indireto de restaurar o patriarcado e de varrer para debaixo do tapete os direitos das mulheres e das crianças que estão envolvidas. 
CST: Um dos depoimentos destacados pelos diretores do filme In Nomine Patris é o do deputado europeu Alain Lipietz, no qual ele chama atenção sobre o fato de os movimentos de pais reivindicarem seus DIREITOS sobre os filhos (e não seus DEVERES enquanto progenitores), argumentando que, no limite, trata-se de um regresso à velha condição patriarcal, centrada na noção de que os filhos ao homem pertencem. O que você acha desse argumento?

MD: As reivindicações desse tipo de movimento fazem da criança uma espécie de propriedade do pai, o que nos leva de novo à velha noção fantasmática de que embrião é uma simples extensão do pai colocada no ventre da mulher que se torna sua propriedade. Sim, essa na verdade é uma regressão quanto ao reconhecimento dos direitos das mulheres de controlarem seu próprio corpo, e poder-se-ia falar também do direito das crianças de não serem apropriadas como um bem que pertença a seu genitor. Em lugar da partilha desejada, que seria, em tese, justa, há muitos elementos de regressão essencialista e biologizante no discurso masculinista, elementos que são facilmente banalizados na psicologia popular e numa certa romantização do papel dos pais como figuras de autoridade, muito mais que de partilha eqüitativa.

Nossa sociedade heterossexista parece estar aberta a reivindicações de qualquer homem desde que ele acione 0 discurso do direito das crianças. Talvez porque isso corresponda a uma heterossexualidade ameaçada pelas novas liberdades das mulheres e pelo reconhecimento dos direitos das minorias sexuais. Essa nova romantização do papel do pai reflete talvez também nossa inquietude diante de um egoísmo e de um individualismo crescente dos homens, que violentam ou abandonam freqüentemente mulheres e filhos em nome de seus interesses privados. Isso torna mais sedutora a promessa masculinista de uma humanização dos homens e de uma partilha igualitária das tarefas parentais. Eles exploram habilmente a demanda do feminismo liberal, que buscava na implicação individual dos homens a solução do problema da opressão sistêmica das mulheres a quem a sociedade delega o trabalho não assalariado de ocupação com as crianças e, enfim, da gestão da vida cotidiana. É oportuno lembrar que as feministas mais radicais não tinham feito esse cerco individual aos homens. Elas queriam mais uma revolução social, como a criação de creches, de guardas, de uma contrapartida mínima assegurada e de um salário verdadeiro para o trabalho de cuidado do outro. E nesse sentido a recuperação masculinista soa talvez como um apelo à vigilância ante o cerco romântico e heterossexista que sugere que somente a aliança com um homem e a benevolência de um homem em relação à mulher possa trazer soluções aos problemas sistêmicos que vivem os pais autônomos, os pais isolados com os filhos e mesmo os casais com seus filhos. Penso que existe uma responsabilidade do Estado em reconhecer a reprodução e a educação das crianças como funções sociais essenciais que devem ser protegidas e financiadas tanto quanto os investimentos logísticos 
nas estradas, nas pontes, o sistema de educação, etc. É necessário resistir a uma reprivatização nesse sentido: pode-se ver que os objetivos masculinistas refletem os objetivos neoliberais, onde se tenta convencer as pessoas de que a privatização e a boa vontade dos dominantes é a resposta aos problemas de iniqüidade e de opressão sistêmica que se observa no mundo. Nesse sentido, o masculinismo é verdadeiramente um movimento de direita.

Ottawa, julho de 2005.

\section{Referências bibliográficas}

AREND, Silvia Maria Fávero. "Paradoxos do Direito de Família no Brasil: uma análise à luz da História Social da Família". In: SOUZA, Ivone M. C. Coelho de (Org.). Casamento: uma escuta além do Judiciário. Florianópolis: VOXLEGEM, 2006. v. 1, p. 103-115.

BRASIL. Lei 10.406, de 10 de janeiro de 2002.

BRASIL. Lei 9.099, de 13 de junho de 2008.

CÔTÉ, Denyse. La garde partagée: L'équité en question. Montréal: Les Éditions du Remue-ménage, 2000.

. "La garde partagée des enfants: nouvelles solidarités parentales ou renouveau patriarcal?" Nouvelles Questions Féministes, v. 23, n. 3, p.80-95, 2004.

DIAS, Maria Berenice. Manual de Direito das Famílias. São Paulo: Editora Revista dos Tribunais, 2007.

DOLTO, Françoise. Quando os pais se separam. Rio de Janeiro: Jorge Zahar, 1989.

DUFRESNE, Martin; PALMA, Hélène. "Autorité parentale conjointe: le retour de la loi du père". Nouvelles Quéstions Féministes, Lausanne: Éditions Antipodes, v. 21, n. 2., p. p. 31-54, 2002.

IN NOMINE PATRIS - Ce que veulent les mouvements des pères. Direção: Myriam Tonelotto e Marc Hansmann. França, 2005. 1 DVD, son., color.

LEITE, Eduardo de Oliveira. Famílias monoparentais: a situação jurídica de pais e mães separados e dos filhos na ruptura da vida conjugal. São Paulo: Editora Revista dos Tribunais, 2003.

POUSSIN, Gerard; MARTIN-LEBRUN, Elisabeth. Os filhos do divórcio. Psicologia da separação parental. Lisboa: Terramar, 1999.

Transcrição da entrevista: Christian Abes Tradução: Helena Heloisa Fava Tornquist Revisão: Carmen Susana Tornquist 